Article

\title{
New Copper(I) Complex with a Coumarin as Ligand with Antibacterial Activity against Flavobacterium psychrophilum
}

\author{
Maialen Aldabaldetrecu ${ }^{1}$, Mick Parra ${ }^{2,3}$, Sarita Soto ${ }^{4}$, Pablo Arce ${ }^{1}{ }^{(}$, , Mario Tello ${ }^{3}(\mathbb{D}$, \\ Juan Guerrero ${ }^{1, *,+}$ (D) and Brenda Modak ${ }^{2, *,+}$ \\ 1 Laboratory of Coordination Compounds and Supramolecularity, Faculty of Chemistry and Biology, \\ University of Santiago of Chile, 9170002 Santiago, Chile; maialen.aldabaldetrecu@usach.cl (M.A.); \\ pablo.arce@usach.cl (P.A.) \\ 2 Laboratory of Natural Products Chemistry, Centre of Aquatic Biotechnology, Faculty of Chemistry and \\ Biology, University of Santiago of Chile, 9170002 Santiago, Chile; mick.parra@usach.cl \\ 3 Laboratory of Bacterial Metagenomic, Centre of Aquatic Biotechnology, Faculty of Chemistry and Biology, \\ University of Santiago of Chile, 9170002 Santiago, Chile; mario.tello@usach.cl \\ 4 Laboratory of Biochemistry and Oral Biology, Faculty of Odontology, University of Chile, \\ 8380000 Santiago, Chile; sarita.soto@usach.cl \\ * Correspondence: juan.guerrero@usach.cl (J.G.); brenda.modak@usach.cl (B.M.); \\ Tel.: +56-2-27181056 (J.G.); +56-2-27181147 (B.M.) \\ + These authors contributed equally to this work.
}

Received: 18 June 2020; Accepted: 10 July 2020; Published: 13 July 2020

\begin{abstract}
A new copper (I) complex, $\left[\mathrm{Cu}\left(\mathrm{NN}_{1}\right)_{2}\right]\left(\mathrm{ClO}_{4}\right)$, was synthesized, where $\mathrm{NN}_{1}$ was a imine ligand 6-((quinolin-2-ylmethylene)amino)-2H-chromen-2-one obtained by a derivatization of natural compound coumarin. The structural characterization in solution was done by NMR techniques, UV-Vis and cyclic voltammetry. The potential antibacterial effect of $\left[\mathrm{Cu}\left(\mathrm{NN}_{1}\right)_{2}\right]\left(\mathrm{ClO}_{4}\right)$, was assessed for F. psychrophilum isolated 10094. F. psychrophilum is a Gram-negative bacterium which causes diseases such as bacterial cold-water disease and rainbow trout fry syndrome, causing large economic losses in the freshwater salmonid aquaculture industry. This complex show to have antibacterial activity against $F$. psychrophilum 10094 at non-cytotoxic concentration in cell line derived from trout (F. psychrophilum $10094 \mathrm{IC}_{50} 16.0 \pm 0.9$; RT-GUT IC $5053.0 \pm 3.1 \mu \mathrm{g} / \mathrm{mL}$ ).
\end{abstract}

Keywords: coumarin; copper (I); coordination compounds; F. psychrophilum; antibacterial activity

\section{Introduction}

Flavobacterium psychrophilum is a Gram-negative bacterium, causative of septicemic disease "cold-water disease" (CWD) or "rainbow trout fry syndrome" (RTFS) in freshwater fish species worldwide and increased susceptibility to other diseases [1] generating serious economic losses. It is also present in non-salmonid fish as Anguilla anguilla, Plecoglossus altivelis and Tinca tinca [2]. In Chile, the second largest farmed salmon producer in the world after Norway, Flavobacterium psychrophilum is the fourth pathogen that produces more mortalities in Rainbow trout, after Piscirickettsia salmonis, IPNV and Vibrio, considered within high risk diseases [3]. The control and prophylactic strategies are based mainly on the use of antibiotics and vaccination. The antibiotics used in Chile are mainly florfenicol and oxytetracycline [4,5]. However, the indiscriminate antibiotic use produces alterations of the bacteria flora in the aquatic environment inducing the appearance of resistant bacteria [4], and potentially transfer resistance to pathogens terrestrial animals and humans [6]. Identifying novel antibacterial drugs is therefore of critical importance and natural products are an excellent source for 
such discoveries. The plant kingdom constitutes a source of new chemicals, which may be important for their potential use as antibacterial. One natural compound that has been studied for its antibacterial properties is coumarin. Coumarin is basically made up of a benzene moiety fused with an alpha-pyrone ring named as benzopyrone [7]. Various naturally isolated coumarins, as well as their chemically modified analogs, are active against numerous bacterial strains, including those which have developed multidrug resistance [7]. Coumarin (1-benzopyran-2-one) itself has a low antibacterial activity, but its derivatives as aegelinol and agasyllin have shown significant antibacterial activity against clinically isolated Gram-positive and Gram-negative bacterial strains such as Staphylococcus aureus, Salmonella typhi, Enterobacter cloacae and Enterobacter aerogenes [7].

On the other hand, in the search for new treatments and as an alternative to antibiotics, the antibacterial properties of various metals, including copper, have been studied in recent years. Several researchers have reported the antibacterial effect of copper compounds in bacteria, such as Salmonella enterica, Campylobacter jejuni and Escherichia coli [7-9].

There are several mechanisms of action described for the both $\mathrm{Cu}(\mathrm{I})$ and $\mathrm{Cu}(\mathrm{II})$ complexes, one of them is the oxidative stress. Few works of antibacterial activity of $\mathrm{Cu}(\mathrm{I})$ was published, however the redox activity of $\mathrm{Cu}(\mathrm{I})$ makes it a powerful catalyst of Fenton and Haber-Weiss type reaction, which lead to the generation of the extremely reactive hydroxyl radical and less dangerous reactive oxygen species (ROS). The hydroxyl radical can react with a wide range of biologic molecules, including DNA, causing cellular irreversible damage $[10,11]$.

Based on this background, our target was to develop a new compound, based on a product such as coumarin, which together with copper, formed a complex with good antibacterial activity with nontoxic concentrations of copper. In this study, we report the synthesis of a new $\mathrm{Cu}(\mathrm{I})$ coordination complex $\left[\mathrm{Cu}\left(\mathrm{NN}_{1}\right)_{2} \mathrm{ClO}_{4}\right.$, (Figure 1) where $\mathrm{NN}_{1}=6$-((quinolin-2-ylmethylene)amino)-2H-chromen-2-one, a ligand derivate from coumarin 1-benzopyran-2-one, which presented a remarkable antibacterial activity against Flavobacterium psychrophilum, at non-cytotoxic concentrations.

\section{Results and Discussion}

\subsection{Synthesis of $\mathrm{Cu}(\mathrm{I})$ Coordination Compound $\left[\mathrm{Cu}\left(\mathrm{NN}_{1}\right)_{2}\right] \mathrm{ClO}_{4}$, Where $\mathrm{NN}_{1}$ Is a Ligand Obtained from Coumarin 1-benzopyran-2-one}

A new imine ligand 6-((quinolin-2-ylmethylene)amine)-2H-chromen-2-one $\left(\mathrm{NN}_{1}\right)$ derivate from coumarin and their homoleptic $\mathrm{Cu}(\mathrm{I})$ complex of formula $\left[\mathrm{Cu}\left(\mathrm{NN}_{1}\right)_{2}\right] \mathrm{ClO}_{4}$ were prepared in good yield and high purity.

The $\mathrm{NN}_{1}$ ligand was obtained by several steps as showed in the scheme of Figure 1, that involved nitration of coumarin by knowledge nitration method [12], and its subsequent reduction to 6-aminocoumarin with Fe powder [13]. The condensation reaction of this amine with 2-quinoline-carboxaldehyde by microwave assisted reaction yield the imine ligand $\mathrm{NN}_{1}$, as a straw yellow crystalline compound (Figure 1) [14].

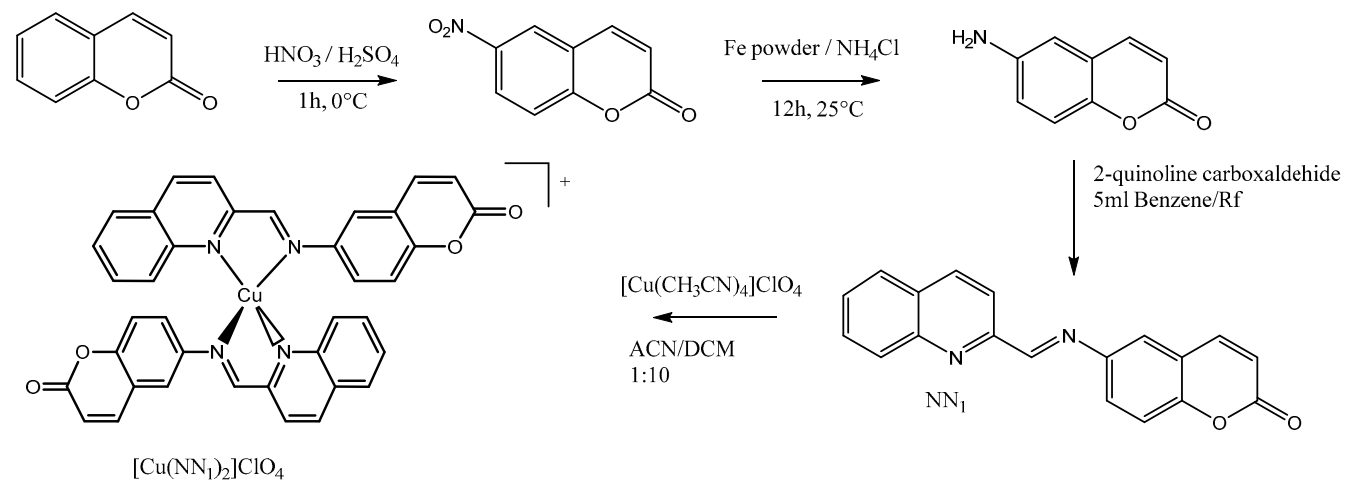

Figure 1. Synthesis scheme $\left[\mathrm{Cu}\left(\mathrm{NN}_{1}\right)_{2}\right] \mathrm{ClO}_{4}$. 
Finally, the reaction of two equivalents of $\mathrm{NN}_{1}$, with an equivalent of $\left[\mathrm{Cu}\left(\mathrm{CH}_{3} \mathrm{CN}\right)_{4}\right] \mathrm{ClO}_{4}$ precursor complex under mild reaction conditions produces a purple solution from which the complex were obtained in high purity as microcrystalline power [15-17].

\subsection{Structural Characterization NMR}

${ }^{1} \mathrm{H}$ NMR spectra supported the structure of all intermediate products (Figure 2 and Figures S5-S16). An unequivocal structure of $\mathrm{NN}_{1}$ and complex $\left[\mathrm{Cu}\left(\mathrm{NN}_{1}\right)_{2}\right] \mathrm{ClO}_{4}$ were established by a concerted use of 1D, ${ }^{1} \mathrm{H},\left\{{ }^{1} \mathrm{H}\right\}{ }^{13} \mathrm{C}$ NMR and 2D COSY, ${ }^{1} \mathrm{H}^{13} \mathrm{C} \mathrm{HSQC},{ }^{1} \mathrm{H}^{13} \mathrm{C}$ HMBC and ${ }^{1} \mathrm{H}^{15} \mathrm{~N}$ HMBC (Figures S3 and S4). The unequivocal signals assignment $\left({ }^{1} \mathrm{H}\right.$ and $\left.{ }^{13} \mathrm{C}\right)$ are reported in experimental.

The unambiguous proton and carbon signals assignment of complex and ligand was performed as follows: all protons and carbons bonded together were identified by HSQC spectra. The singlet proton signal placed around to $9.00 \mathrm{ppm}$, assigned to imine proton was corroborated for ${ }^{1} \mathrm{H}^{15} \mathrm{~N} \mathrm{HMBC}$ and ${ }^{1} \mathrm{H}{ }^{13} \mathrm{C}$ HMBC spectra which also confirming the formation of imine group linking the quinoline and coumarin fragments as shown in Figure 2. The discrimination between the different protons spin system for each molecular fragment was realized by concerted analysis of ${ }^{1} \mathrm{H}^{13} \mathrm{C} \mathrm{HMBC}$ and COSY spectra. The quaternary carbon and relative position of oxygens atom was established by the ${ }^{1} \mathrm{H}{ }^{13} \mathrm{C} \mathrm{HMBC}$ technique. Characteristic proton and carbon spectra were observed for free ligand recorded in $\mathrm{CDCl}_{3}$ with expected frequency ranges for this type of organic molecules. On the contrary, even considering the impact of the solvent, the ligand signals in the complex show the effect of metal coordination which shifts the imine proton to high frequencies. We can presume that this effect is expected by the extraction of electronic density from nitrogen by the metal complexation. However, copper (I) is a weak Lewis acid to explain this high deshielding by itself, but can synergistically act with magnetic currents of the aromatic ring of the ligand that are placed orthogonally to each other to increase the deshielding effect on imine proton and explain shielding effect on H8 (5.94 ppm).

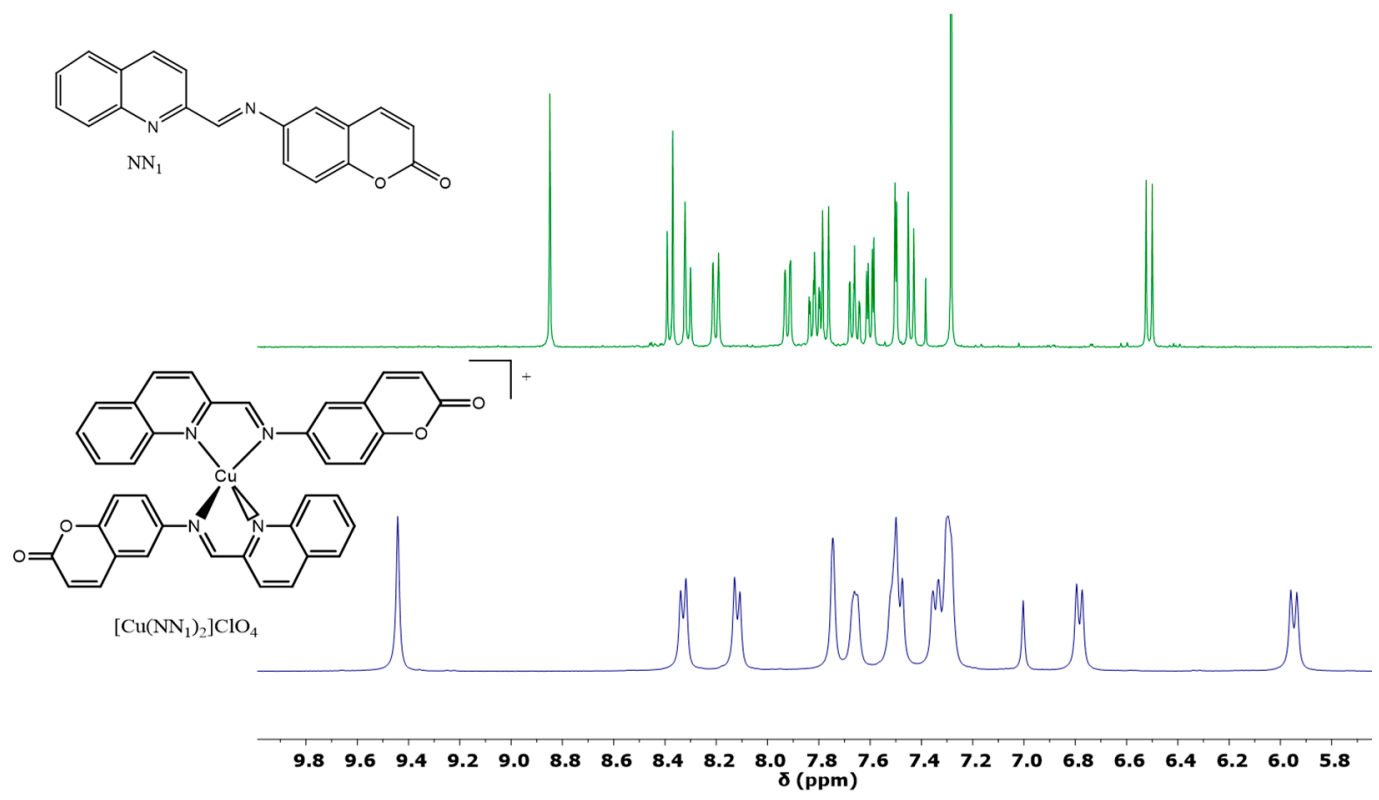

Figure 2. ${ }^{1} \mathrm{H}-\mathrm{RMN}$ in $\mathrm{CDCl}_{3}, \mathrm{NN}_{1}$ (green) and $\left[\mathrm{Cu}^{\mathrm{I}}\left(\mathrm{NN}_{1}\right)_{2}\right]\left(\mathrm{ClO}_{4}\right)$ (blue) in $\mathrm{CDCl}_{3}$.

\subsection{Characterization in Solution}

\subsubsection{UV-Vis}

Electronic spectra data of the complexes and ligands in $\mathrm{CHCl}_{3}$ are shown in Figure 3. The spectral region below $400 \mathrm{~nm}$ in complex correspond at $\pi$ to $\pi^{*}$ intraligand transition bands, which are similar profile of free ligand, but undergo a red-shift upon complexation to copper(I) in around $20 \mathrm{~nm}$. 


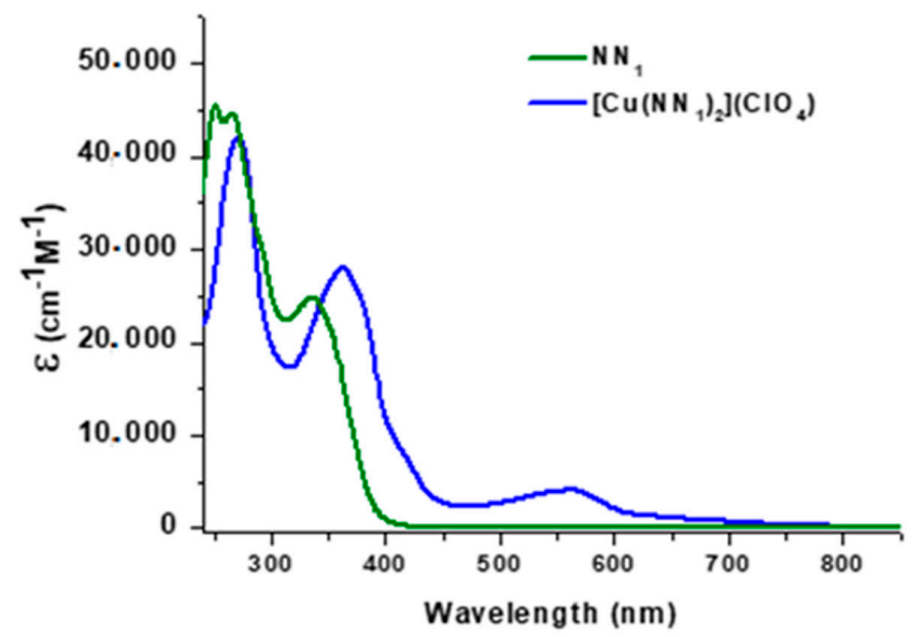

Figure 3. UV-Vis spectra for $\mathrm{NN}_{1}$ ligand (green) and complex $\left[\mathrm{Cu}\left(\mathrm{NN}_{1}\right)_{2}\right] \mathrm{ClO}_{4}$ (blue).

The broadband centered in $562 \mathrm{~nm}$ for the $\left[\mathrm{Cu}\left(\mathrm{NN}_{1}\right)_{2}\right]^{+}$complex correspond at one metal to ligand charge transfer band (MLCT) (Figure 3) in accordance with their intensity and energy. In addition, this band showed a similar spectral profile to shown by homoleptic $\left[\mathrm{Cu}(\mathrm{biq})_{2}\right]^{+}$complex $(\lambda$-max TCML is $550 \mathrm{~nm}$ ) which biq ligand (where biq correspond to 2,2'-biquinoline) has structural similarities with $\mathrm{NN}_{1}$ [18]. Like in that complex, this MLCT is a transition of HOMO mainly centered in $\mathrm{Cu}(\mathrm{I})$ with full $\mathrm{d}^{10}$ shell, toward LUMO formed by $\pi^{*}$ orbital of the 2-imine-quinoline fragment of $\mathrm{NN}_{1}$ ligand. Another band observed as a shoulder around to $416 \mathrm{~nm}$, can correspond to a second MLCT transition from metal to $\pi^{*}$ orbital of coumarin fragment of ligand. The assignment of second MLCT is supported by its most blue-shifted position in accordance with the fact that the $\pi^{*}$ orbital of coumarin is of greater energy than $\pi^{*}$ orbital of the 2-imine-quinoline fragment, appearing overlapped by the more intense intraligand bands.

No significant changes in the spectral bands were observed at $72 \mathrm{~h}$ after the solution was prepared showing high stability in that solvent and air-exposed at room temperature.

\subsubsection{Cyclic Voltammetry}

Voltammetry studies were also performed in order to determine the effect of new $\mathrm{NN}_{1}$ ligand on the $\mathrm{Cu}(\mathrm{II}) / \mathrm{Cu}(\mathrm{I})$ oxidation potential considering the well-known fact of high influence of ligands on the metal-centered HOMO energy. Consequently, measurements were registered at room temperature in -1.10 to $+1.30 \mathrm{~V}$ vs $\mathrm{Ag} / \mathrm{AgCl}$ potential range. Figure 4 shows representative cyclic voltammograms for ligand $\left(\mathrm{NN}_{1}\right)$ and respective coordination complex $\left[\mathrm{Cu}\left(\mathrm{NN}_{1}\right)_{2}\right]\left(\mathrm{ClO}_{4}\right)$ in dichloromethane.

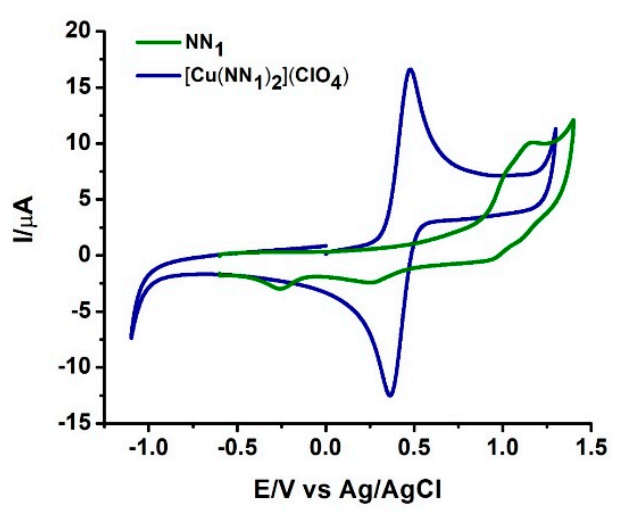

Figure 4. Characteristic cyclic voltammograms for ligand $\mathrm{NN}_{1}$ (green) and coordination complex $\left[\mathrm{Cu}\left(\mathrm{NN}_{1}\right)_{2}\right]\left(\mathrm{ClO}_{4}\right)$ (blue). $\mathrm{NN}_{1}$ and $\left[\mathrm{Cu}\left(\mathrm{NN}_{1}\right)_{2}\right]\left(\mathrm{ClO}_{4}\right)$ in $\left(\mathrm{CH}_{2} \mathrm{Cl}_{2}\right)$ and $0.1 \mathrm{M}$ TBAP. Potential are related to $\mathrm{Ag} / \mathrm{AgCl}$ at $100 \mathrm{mV} / \mathrm{S}$ scan rate. 
The free ligand undergoes two irreversible oxidation waves within the potential window allowed by the solvent at potential greater than $0.9 \mathrm{~V}$. On the contrary, the complex $\left[\mathrm{Cu}\left(\mathrm{NN}_{1}\right)_{2}\right] \mathrm{ClO}_{4}$, shows only one quasireversible oxidation process assignable to the $\mathrm{Cu}(\mathrm{II}) / \mathrm{Cu}(\mathrm{I})$ couple in $\left.\mathrm{E}_{1 / 2}=0.426 \mathrm{~V}(\Delta \mathrm{E}=114 \mathrm{mV})\right]$. Scan rate dependence reveals that the copper complexes are oxidized in a diffusion-controlled step (Figure S18).

The oxidation potentials occur at less positive potentials compare well to these reported for similar, $\left.[\mathrm{Cu} \text { (biq) })_{2}\right] \mathrm{ClO}_{4}$ complex which exhibits a value $\mathrm{E}_{1 / 2}=0.96 \mathrm{~V}$ versus $\mathrm{Ag} / \mathrm{AgCl}$ in $\mathrm{CH}_{2} \mathrm{Cl}_{2}$ [18]. The lower oxidation potential for the new $\mathrm{Cu}(\mathrm{I})$ complex $\left[\mathrm{Cu}\left(\mathrm{NN}_{1}\right)_{2}\right] \mathrm{ClO}_{4}$, was associated with distortion of the ideal geometry (tetrahedral) for the metal center toward a more flattened structure which is associated with increased of its reactivity [19] which is an interesting property to designed biologically active drugs.

\subsection{Antibacterial Activity against Flavobacterium psychrophilum}

\subsubsection{Antibacterial Test}

The antibacterial activity of $\left[\mathrm{Cu}\left(\mathrm{NN}_{1}\right)_{2}\right] \mathrm{ClO}_{4}$ complex against F. psychrophilum 10094, $\left[\mathrm{Cu}\left(\mathrm{CH}_{3} \mathrm{CN}\right)_{4}\right]_{\mathrm{ClO}_{4}}$ salt and coumarin was evaluated, for which Minimum Inhibitory Concentration MIC, Minimum Bactericidal Concentration MBC and Half Maximal Inhibitory Concentration $\mathrm{IC}_{50}$ of these compounds were determined using concentrations between $512-\mu \mathrm{g} / \mathrm{mL}$ to $2 \mu \mathrm{g} / \mathrm{mL}$. The results are shown in Table 1. MIC and MBC values do not show standard deviations since each replicate separately showed a similar behavior according to the evaluated treatment (View experimental section).The $\mathrm{IC}_{50}$ of the new copper (I) complex was $16.1 \pm 0.9 \mu \mathrm{g} / \mathrm{mL}$, slightly higher in comparison with the IC50 of the $\left[\mathrm{Cu}\left(\mathrm{CH}_{3} \mathrm{CN}\right)_{4}\right] \mathrm{ClO}_{4}(10.4 \pm 0.7)$. However, the concentration of $\left[\mathrm{Cu}\left(\mathrm{NN}_{1}\right)_{2}\right] \mathrm{ClO}_{4}$ complex necessary to inhibit growth and kill the bacteria (MIC and MBC of $32 \mu \mathrm{g} / \mathrm{mL}$ ) was lower than the observed by the precursor complex (MIC and MBC of $64 \mu \mathrm{g} / \mathrm{mL}$ ). The effect of coumarin on the F. psychrophilum 10094 was only observed at high concentration of the compound $\left(\mathrm{IC}_{50} 160.0 \pm 25.5 \mu \mathrm{g} / \mathrm{mL}, \mathrm{MIC} 512 \mu \mathrm{g} / \mathrm{mL}\right.$ and $\mathrm{MBC}<512 \mu \mathrm{g} / \mathrm{mL}$ ), despite the fact that the antibacterial effect of coumarin in a large number of bacteria has been reported [20]. Thus, the copper (I) complex shown an antibacterial effect more similar to the precursor complex, but with higher potency. Altogether, these data suggest that in the copper $(\mathrm{I})$ complex, the metallic center $\mathrm{Cu}(\mathrm{I})$ is the main responsible for the antibacterial activity against F. psychrophilum 10094.

Table 1. Comparative table of MIC, MBC and $\mathrm{IC}_{50}$ on F. psychrophilum $(n=3)$ at $72 \mathrm{~h}$ post-incubation and $\mathrm{IC}_{50}$ on Chinook salmon embryo (CHSE-214), Salmon Head Kidney-1 (SHK-1) and intestinal epithelial cell line (RT-GUT) cells ( $n=6 ; 3$ independent replicas) of the copper (I) complex $\left[\mathrm{Cu}\left(\mathrm{NN}_{1}\right)_{2}\right] \mathrm{ClO}_{4}$. The precursors Coumarin and $\mathrm{Cu}(\mathrm{I})$ salt $\left(\left[\mathrm{Cu}\left(\mathrm{CH}_{3} \mathrm{CN}\right)_{4}\right] \mathrm{ClO}_{4}\right)$ were used like control.

\begin{tabular}{|c|c|c|c|c|c|c|}
\hline \multicolumn{4}{|c|}{ Flavobacterium psychrophilum 10094} & \multirow{2}{*}{$\begin{array}{c}\text { CHSE-214 } \\
\mathrm{IC}_{50} \\
\text { (cellular) } \\
\mu \mathrm{g} / \mathrm{mL}\end{array}$} & \multirow{2}{*}{$\begin{array}{c}\text { SHK-1 } \\
\text { IC }_{50} \\
\text { (cellular) } \\
\mu \mathrm{g} / \mathrm{mL}\end{array}$} & \multirow{2}{*}{$\begin{array}{c}\text { RT-GUT } \\
\text { IC }_{50} \\
\text { (cellular) } \\
\mu \mathrm{g} / \mathrm{mL}\end{array}$} \\
\hline Compounds & $\begin{array}{c}\text { IC }_{50} \text { (bacterial) } \\
\mu \mathrm{g} / \mathrm{mL}\end{array}$ & $\mathrm{MIC} \mu \mathrm{g} / \mathrm{mL}$ & $\mathrm{MBC} \mu \mathrm{g} / \mathrm{mL}$ & & & \\
\hline Coumarin & $160.0 \pm 25.5^{\mathrm{a}}$ & 512 & $>512$ & $>512$ & $>512$ & $>512$ \\
\hline$\left[\mathrm{Cu}\left(\mathrm{CH}_{3} \mathrm{CN}\right)_{4}\right] \mathrm{ClO}_{4}$ & $10.4 \pm 0.7^{\mathbf{b}}$ & 64 & 64 & $59.4 \pm 4.1^{\mathrm{a}}$ & $159 \pm 44.6^{a}$ & $233.9 \pm 19.5^{\mathrm{a}}$ \\
\hline$\left[\mathrm{Cu}\left(\mathrm{NN}_{1}\right)_{2}\right] \mathrm{ClO}_{4}$ & $16.1 \pm 0.9^{c}$ & 32 & 32 & $29.1 \pm 1.4^{b}$ & $30.8 \pm 1.3^{\mathbf{b}}$ & $53.0 \pm 3.1^{\mathbf{b}}$ \\
\hline
\end{tabular}

Statistical analysis was performed independently for the bacteria and for each cell line tested where different letters $(\mathbf{a}, \mathbf{b}, \mathbf{c})$, mean statistically significant differences between treatments. $(p<0.05)$.

In this sense, the increase in antibacterial capacity observed by the copper (I) complex, $\left[\mathrm{Cu}\left(\mathrm{NN}_{1}\right)_{2}\right] \mathrm{ClO}_{4}$, could be given because the coordination of the metal ion with $\mathrm{NN}_{1}$ ligand which would increase the cellular permeability increasing the amount of copper inside the cell [21]. The above occur since the metal polarity is reduced by chelation of copper (I) complex is with $\mathrm{NN}_{1}$ ligand, increasing the delocalization of $\pi$-electrons and enhances the lipophilicity of the complex. This increased lipophilicity 
in turn enhances the penetration of the complex into lipid membranes and blocking of metal binding sites on the enzymes of the microorganisms [22].

Although the antibacterial mechanism of this complex was not addressed in this work, it is known that copper ions are available to produce Fenton-type reactions, generating hydroxyl radicals, which could induce oxidative stress, either at the cytoplasm or inner membrane, which could kill the bacteria $[23,24]$.

Because a high concentration of copper can be toxic, we determine the amount of copper present in the copper (I) complex and in the precursor of the complex. As show in Table 2 the $\mathrm{IC}_{50}$, MIC as well as in the MBC of the precursor salt have 2.3 times, respectively of amount of copper in relation to the complex with the $\mathrm{NN}_{1}$ ligand, that is to say, the percentage of copper present in the precursor is $19.5 \%$, while in the complex is only $8.3 \%$. These results demonstrate the importance of the presence of the $\mathrm{NN}_{1}$ ligand in the antibacterial activity decreasing the amount of copper needed and therefore toxicity.

Table 2. Comparative table of amount cooper in $\mathrm{MIC}, \mathrm{MBC}$ and $\mathrm{IC}_{50}$ on F. psychrophilum of the copper (I) complex $\left[\mathrm{Cu}\left(\mathrm{NN}_{1}\right)_{2}\right] \mathrm{ClO}_{4}$ and precursor $\mathrm{Cu}(\mathrm{I})$ salt $\left(\left[\mathrm{Cu}\left(\mathrm{CH}_{3} \mathrm{CN}\right)_{4}\right] \mathrm{ClO}_{4}\right)$.

\begin{tabular}{ccccc}
\hline \multicolumn{2}{c}{ Copper (I) Complex $\left[\mathrm{Cu}\left(\mathrm{NN}_{\mathbf{1}}\right)_{2}\right] \mathrm{ClO}_{4}$} & \multicolumn{2}{c}{ Precursor Salt $\left[\mathrm{Cu}\left(\mathrm{CH}_{\mathbf{3}} \mathrm{CN}\right)_{4}\right] \mathrm{ClO}_{4}$} \\
\hline & Amount Total $(\mu \mathrm{g})$ & Amount $\mathrm{Cu}(\mu \mathrm{g})$ & Amount Total $(\mu \mathrm{g})$ & Amount $\mathrm{Cu}(\mu \mathrm{g})$ \\
\hline $\mathrm{IC}_{50}$ & 16.1 & 1.3 & 10.4 & 2.0 \\
$\mathrm{MIC}$ & 32 & 2.7 & 64 & 12.5 \\
$\mathrm{MBC}$ & 32 & 2.7 & 64 & 12.5 \\
\hline
\end{tabular}

\subsubsection{Cytotoxicity Test}

Since F. psychrophilum is a bacterial pathogen that affects a wide variety of salmonids, we evaluated the toxicity of the $\left[\mathrm{Cu}\left(\mathrm{NN}_{1}\right)_{2}\right] \mathrm{ClO}_{4}$ complex in three different cell lines, Chinook salmon embryo (CHSE-214), Salmon Head Kidney-1 (SHK-1) and intestinal epithelial cell line (RT-GUT). For this experiment $1 \times 10^{5}$ cells were treated with the different compounds (coumarin, $\mathrm{Cu}(\mathrm{I})$ salt and copper (I) complex) in a range of concentrations between $512 \mu \mathrm{g} / \mathrm{mL}$ and $2 \mu \mathrm{g} / \mathrm{mL}$, incubated at $16^{\circ} \mathrm{C}$ for $24 \mathrm{~h}$. The cellular viability was analyzed by flow cytometry and the results are shown in Table 1 . In the copper (I) complex and precursor complex $\left[\mathrm{Cu}\left(\mathrm{CH}_{3} \mathrm{CN}\right)_{4}\right] \mathrm{ClO}_{4}$, a concentration-dependent toxicity was observed. On the other hand, the $\mathrm{IC}_{50}$ of each compound was different depending on the cell line used, it was observed that in the case of the copper (I) complex the compound is more toxic in cell lines derived from salmon, with an $\mathrm{IC}_{50}$ of $29.1 \pm 1.4 \mu \mathrm{g} / \mathrm{mL}$, while it is less toxic in a line derived from trout with an $\mathrm{IC}_{50}$ of $53.0 \pm 3.1 \mu \mathrm{g} / \mathrm{mL}$ in RT-GUT. Similar effect is observed with the precursor complex, where the compound is more toxic in the CHSE-214 cell line with an $\mathrm{IC}_{50}$ of $59.4 \pm 4.1 \mu \mathrm{g} / \mathrm{mL}$, being less toxic in the RT-GUT cell line with an $\mathrm{IC}_{50}$ of $233.9 \pm 19.5 \mu \mathrm{g} / \mathrm{mL}$. This difference in the effect of copper administration is also observed in vivo when different salmonid species are fed with $\mathrm{CuSO}_{4}$, where the adverse effects depend on the species and growth stage [25]. Finally, coumarin toxicity was not observed in any of the cell lines used. The increase in the toxicity of the copper (I) complex compared to coumarin, was probably due to the ability of coumarin to permeate the membrane [21], functioning as a carrier for the copper metal center of the complex. On the other hand, analyzing the effect of the copper (I) complex, $\left[\mathrm{Cu}\left(\mathrm{NN}_{1}\right)_{2}\right] \mathrm{ClO}_{4}$, on the different cell lines, our results shows that the $\mathrm{NN}_{1}$ ligand increase the toxicity of $\left[\mathrm{Cu}\left(\mathrm{NN}_{1}\right)_{2}\right] \mathrm{ClO}_{4}$, more in eukaryotic cells than for prokaryotic cells. This effect is interesting, since it is necessary to carry out experiments to elucidate the mechanism of action of $\left[\mathrm{Cu}\left(\mathrm{NN}_{1}\right)_{2}\right]_{\mathrm{ClO}_{4}}$ in both prokaryotic and eukaryotic cells and how the cell wall of prokaryotic cells influences the toxicity of $\left[\mathrm{Cu}\left(\mathrm{NN}_{1}\right)_{2}\right] \mathrm{ClO}_{4}$. In addition, although a higher toxicity of $\left[\mathrm{Cu}\left(\mathrm{NN}_{1}\right)_{2}\right] \mathrm{ClO}_{4}$ is observed in all cell lines, compared to the copper salt, $\left[\mathrm{Cu}\left(\mathrm{CH}_{3} \mathrm{CN}\right)_{4}\right] \mathrm{ClO}_{4}$, more promising results could be obtained in fish. The stability to stomach and intestinal $\mathrm{pH}$, as well as capacity to be absorbed in the gut, are variable not present in cultures conditions producing that in general in vivo models show greater resistance than in vitro studies [26-28]. Interestingly, the results showed that the RT-GUT cell line was more resistant to $\left[\mathrm{Cu}\left(\mathrm{NN}_{1}\right)_{2}\right] \mathrm{ClO}_{4}$, suggesting that this compound could be applied at the 
mucosa level in rainbow trout either in baths or through food, although still remains to determine if this compound have toxic effects on the fish to the concentration assessed with F. psychrophilum.

\section{Experimental Section}

\subsection{General Methods}

All the chemicals were purchased commercially and used without further purification. ${ }^{1} \mathrm{H},{ }^{13} \mathrm{C}$ NMR and 2D spectra were recorded on a Bruker Avance Neo $400 \mathrm{MHz}$ spectrometer $(400.133 \mathrm{MHz}$ for ${ }^{1} \mathrm{H}, 40.559 \mathrm{MHz}$ for ${ }^{15} \mathrm{~N}$ and $100.613 \mathrm{MHz}$ for ${ }^{13} \mathrm{C}$, (University of Santiago of Chile, Santiago, RM, Chile) equipped with a $5 \mathrm{~mm}$ multinuclear broad-band dual probehead, incorporating a z-gradient coil. All the measurement was done in $\mathrm{CDCl}_{3}$ at $300 \mathrm{~K}$. Chemical shifts (in ppm) for ${ }^{1} \mathrm{H}$ and ${ }^{13} \mathrm{C}$ were calibrated respect to the residual protonated signal of the solvent (7.26 and $77 \mathrm{ppm}$ respectively) and reported relative to $\mathrm{Me}_{4} \mathrm{Si}$. The ${ }^{15} \mathrm{~N}$ signal in ${ }^{1} \mathrm{H}^{15} \mathrm{~N}$ HMBC were calibrated relative to $\mathrm{CH}_{3} \mathrm{NO}_{2}$ $(90 \%)$ in $\left.\mathrm{CDCl}_{3}\right)$. The following abbreviations were used to explain the multiplicities: $\mathrm{s}=$ singlet, $\mathrm{d}=$ doublet, $\mathrm{m}=$ multiplet. Electronic spectra were recorded on a PerkinElmer UV-VIS Lambda 25 spectrophotometer (University of Santiago of Chile, Santiago, RM, Chile) at room temperature, wavelength range between 200 and $1100 \mathrm{~nm}$ from $1.5 \times 10^{-5} \mathrm{~mol} / \mathrm{L}$ solutions in dichloromethane to $\mathrm{NN}_{1}$ and $\left[\mathrm{Cu}\left(\mathrm{NN}_{1}\right)_{2}\right] \mathrm{ClO}_{4}$. Electrochemical behavior was studied by cyclic voltammetry using a potentiostat $\mathrm{CHI} 620 \mathrm{E}$ by $\mathrm{CH}$ instrument equipment supplied with the electrochemical analyzer $\mathrm{CHI}$ software (University of Santiago of Chile, Santiago, RM, Chile). A standard electrochemical three electrode cell by $\mathrm{CH}$ instruments, $10 \mathrm{~mL}$ volume provided with a glassy carbon working electrode, a platinum wire auxiliary electrode and a $\mathrm{AgCl} / \mathrm{Ag}$ reference electrode. Measurements were performed at room temperature and $\mathrm{N}_{2}$ atmosphere in $2 \mathrm{mmol} / \mathrm{L}$ to $\mathrm{NN}_{1}$ and $1 \mathrm{mmol} / \mathrm{L}$ to $\left[\mathrm{Cu}\left(\mathrm{NN}_{1}\right)_{2}\right] \mathrm{ClO}_{4}$ in dichloromethane solutions using tetrabutylammonium perchlorate (c.a. $0.1 \mathrm{~mol} / \mathrm{L}$ ) as supporting electrolyte, at several scan rates (50 to $300 \mathrm{mVs}^{-1}$ range). The potentials were informed as $\mathrm{E}_{1 / 2}$ $v / s \mathrm{Ag} / \mathrm{AgCl}$.

\subsection{6-Nitrocoumarin}

Coumarin was nitrated with mixed acid in an ice bath. Coumarin $(1.00 \mathrm{~g}, 7.1 \mathrm{mmol})$ was dissolved in conc. $\mathrm{H}_{2} \mathrm{SO}_{4}(5 \mathrm{~mL})$ and temperature was maintained at $0{ }^{\circ} \mathrm{C}$ and then $5 \mathrm{~mL}$ mixed acid $\left(\mathrm{HNO}_{3}\right.$ and $\mathrm{H}_{2} \mathrm{SO}_{4}$ (conc.) in 1:3 volume ratio) was added. The mixture was stirred keeping at $0{ }^{\circ} \mathrm{C}$ for $1 \mathrm{~h}$. Water at $0{ }^{\circ} \mathrm{C}(50 \mathrm{~mL})$ was added to precipitate obtaining A white precipitate of 6-nitrocoumarin. It was then filtered and washed thorough with cold water $(10 \mathrm{~mL})$. The compounds were dried a $60^{\circ} \mathrm{C}$ overnight. The identity of the compound was determined by ${ }^{1} \mathrm{H}$ NMR and used as was obtained. Yield, $1.20 \mathrm{~g}(88 \%) .{ }^{1} \mathrm{H}$ NMR $\left(400.133 \mathrm{MHz}, \mathrm{CDCl}_{3}\right) \delta / \mathrm{ppm} \mathrm{H} 5^{\prime} 8.43\left(\mathrm{~d},{ }^{4} J_{5^{\prime}-7^{\prime}}=2.4 \mathrm{~Hz}, 1 \mathrm{H}\right), \mathrm{H} 7^{\prime} 8.40$ $\left(\mathrm{dd},{ }^{3} J_{7^{\prime}-8^{\prime}}=9.0,{ }^{4} J_{7^{\prime}-5^{\prime}}=2.5 \mathrm{~Hz}, 1 \mathrm{H}\right), \mathrm{H} 4^{\prime} 7.80\left(\mathrm{~d},{ }^{3} J_{4^{\prime}-3^{\prime}}=9.7 \mathrm{~Hz}, 1 \mathrm{H}\right), \mathrm{H} 8^{\prime} 7.47\left(\mathrm{~d},{ }^{3} J_{8^{\prime}-7^{\prime}}=9.0 \mathrm{~Hz}, 1 \mathrm{H}\right)$, $\mathrm{H} 3^{\prime} 6.59\left(\mathrm{~d},{ }^{3} J_{3^{\prime}-4^{\prime}}=9.7 \mathrm{~Hz}, 1 \mathrm{H}\right)$. (Figure S3).

\subsection{6-Aminocoumarin}

Reduction of 6-nitrocoumarin was done using iron powder and ammonium chloride in water. 6-Nitrocoumarin $(1.00 \mathrm{~g}, 5.2 \mathrm{mmol})$ in water $(150 \mathrm{~mL})$ was treated with Fe-powder $(2.00 \mathrm{~g}, 36 \mathrm{mmol})$ and ammonium chloride $(0.24 \mathrm{~g}, 4.5 \mathrm{mmol})$. The mixture was kept in water bath for $12 \mathrm{~h}$ with stirring. A dark brown precipitate was obtained which was then extracted with dichloromethane. 6-aminocoumarin was obtained as yellow precipitate by slowly dichloromethane evaporation finally washed by two times with few milliliters of dry diethyl ether, and the identity of the compound was determined by ${ }^{1} \mathrm{H}$ NMR. Yield, $0.64 \mathrm{~g}(76 \%) .{ }^{1} \mathrm{H}$ NMR $\left(400.133 \mathrm{MHz}, \mathrm{CDCl}_{3}\right) \delta / \mathrm{ppm} \mathrm{H} 4{ }^{\prime} 7.57$ (d, $\left.{ }^{3} J_{4^{\prime}-3^{\prime}}=9.5 \mathrm{~Hz}, 1 \mathrm{H}\right), \mathrm{H}_{8^{\prime}} 7.15\left(\mathrm{~d},{ }^{3} J_{8^{\prime}-7^{\prime}}=8.8 \mathrm{~Hz}, 1 \mathrm{H}\right), \mathrm{H} 7^{\prime} 6.87\left(\mathrm{dd},{ }^{3} J_{7^{\prime}-8^{\prime}}=8.8,{ }^{4} J_{7^{\prime}-5^{\prime}}=2.7 \mathrm{~Hz}, 1 \mathrm{H}\right)$, $\mathrm{H}^{\prime} 6.71\left(\mathrm{~d},{ }^{4} J_{5^{\prime}-7^{\prime}}=2.7 \mathrm{~Hz}, 1 \mathrm{H}\right), \mathrm{H}^{\prime} 6.38\left(\mathrm{~d},{ }^{3} J_{3^{\prime}-4^{\prime}}=9.5 \mathrm{~Hz}, 1 \mathrm{H}\right), \mathrm{NH}_{2} 3.71(\mathrm{~s}, 2 \mathrm{H})$ (Figure S4). 


\subsection{Ligand: $N N_{1}$}

The synthesis was carried out by microwave reaction in a Teflon reactor. In it, 6-amino coumarin $\left(\mathrm{N}_{1}\right)$ $(0.50 \mathrm{~g}, 3.1 \mathrm{mmol})$ and 2-quinoline-aldehyde $(\mathrm{N})(0.49 \mathrm{~g}, 3.1 \mathrm{mmol})$ of were added, solubilizing them in $5 \mathrm{~mL}$ of benzene. It was irradiated for $14 \mathrm{~min}$ obtaining a pale-yellow solid. It was washed with dichloromethane $(30 \mathrm{~mL})$ and ethyl ether $(50 \mathrm{~mL})$. It was recrystallized by solubilizing the powder in hot methanol, filtered on porous glass filter and slowly solvent evaporation at room temperature, obtained a pale-yellow microcrystal. Yield, $0.86 \mathrm{~g}, 92 \% .{ }^{1} \mathrm{H}$ NMR $\left(400.133 \mathrm{MHz}, \mathrm{CDCl}_{3}\right)$ 8/ppm Hi 8.82 $(\mathrm{s}, 1 \mathrm{H}), \mathrm{H} 38.35\left(\mathrm{~d},{ }^{3} J_{3-4}=8.6 \mathrm{~Hz}, 1 \mathrm{H}\right), \mathrm{H} 48.28\left(\mathrm{~d},{ }^{3} J_{7-8}=8.6 \mathrm{~Hz}, 1 \mathrm{H}\right), \mathrm{H} 88.17\left(\mathrm{~d},{ }^{3} J_{7-8}=8.5 \mathrm{~Hz}, 1 \mathrm{H}\right)$, $\mathrm{H} 57.89\left(\mathrm{~d},{ }^{3} J_{5-6}=8.0 \mathrm{~Hz}, 1 \mathrm{H}\right), \mathrm{H} 77.79\left(\mathrm{t},{ }^{3} J_{7-8}=8.5 \mathrm{~Hz},{ }^{3} J_{10-11}=7.7 \mathrm{~Hz}, 1 \mathrm{H}\right), \mathrm{H} 4^{\prime} 7.75\left(\mathrm{~d},{ }^{3} J_{3^{\prime}-4^{\prime}}=9.6\right.$ $\mathrm{Hz}, 1 \mathrm{H}), \mathrm{H6} 7.63\left(\mathrm{t},{ }^{3} J_{5-6}=8.0 \mathrm{~Hz},{ }^{3} J_{6-7}=7.7 \mathrm{~Hz}, 1 \mathrm{H}\right), \mathrm{H} 7^{\prime} 7.57\left(\mathrm{dd},{ }^{3} J_{7^{\prime}-8^{\prime}}=8.7,{ }^{4} J_{5^{\prime}-7^{\prime}}=2.4 \mathrm{~Hz}, 1 \mathrm{H}\right)$, $\mathrm{H} 5^{\prime} 7.47\left(\mathrm{~d},{ }^{4} J_{5^{\prime}-7^{\prime}}=2.3 \mathrm{~Hz}, 1 \mathrm{H}\right), \mathrm{H} 7^{\prime} 7.41(\mathrm{~d}, J=8.8 \mathrm{~Hz}, 1 \mathrm{H}), \mathrm{H} 3^{\prime} 6.48\left(\mathrm{~d},{ }^{3} J_{3^{\prime}-4^{\prime}}=9.5 \mathrm{~Hz}, 1 \mathrm{H}\right) .{ }^{13} \mathrm{C} \mathrm{NMR}$ $\left(100.613 \mathrm{MHz}, \mathrm{CDCl}_{3}\right)$ 8/ppm 194.26 C2, $162.10 \mathrm{Ci}, 160.90 \mathrm{C}^{\prime} 0^{\prime}, 154.76 \mathrm{C} 2,153.28 \mathrm{C} 9^{\prime}, 148.36 \mathrm{C} 9,147.67$ $\mathrm{C}^{\prime}{ }^{\prime}, 143.66 \mathrm{C}^{\prime}{ }^{\prime}, 137.16 \mathrm{C} 4,130.59 \mathrm{C} 7,130.18 \mathrm{C} 8,129.48 \mathrm{C} 10,127.41 \mathrm{C} 6,128.32 \mathrm{C} 5,125.45 \mathrm{C}^{\prime}{ }^{\prime}, 120.30$ C5' 118.88 C3, 118.19 C8', 117.75 C3' (Figures S5 and S6-S11).

\subsection{Coordination Complex $\mathrm{Cu}(\mathrm{I}):\left[\mathrm{Cu}\left(\mathrm{NN}_{1}\right)_{2}\right] \mathrm{ClO}_{4}$}

$\left[\mathrm{Cu}\left(\mathrm{CH}_{3} \mathrm{CN}\right)_{4}\right] \mathrm{ClO}_{4}(0.47 \mathrm{~g}, 1.42 \mathrm{mmol})$ was taken in a $25 \mathrm{~mL}$ double neck round bottom flask dissolved in $\mathrm{CH}_{3} \mathrm{CN}$ by magnetic stirring and under $\mathrm{N}_{2}$ atmosphere. Then, $\mathrm{NN}_{1}(0.86 \mathrm{~g}, 2.852 \mathrm{mmol})$ was added dissolved in $\mathrm{CH}_{3} \mathrm{CN}$ and the reaction was continued under $\mathrm{N}_{2}$ atmosphere and stirring for $1 \mathrm{~h}$. A purple- black precipitate was collected by filtration and dried. The compound was washed with diethyl ether and recrystallized. Yield $0.82 \mathrm{~g}(76 \%) ;{ }^{1} \mathrm{H}$ NMR $\left(400.133 \mathrm{MHz}, \mathrm{CDCl}_{3}\right)$ 8/ppm Hi 9.72 (s, 1H), H3 $8.61(\mathrm{~d}, J=8.3 \mathrm{~Hz}, 1 \mathrm{H}), \mathrm{H} 48.40(\mathrm{~d}, J=8.3 \mathrm{~Hz}, 1 \mathrm{H}), \mathrm{H}^{\prime}$ 8.08-8.00 (m, 1H), H8 7.96-7.90 $(\mathrm{m}, 1 \mathrm{H}),\left(\mathrm{H7}{ }^{\prime}, \mathrm{H} 5\right) 7.78(\mathrm{t}, J=7.0 \mathrm{~Hz}, 2 \mathrm{H}),\left(\mathrm{H7}, \mathrm{H6}, \mathrm{H} 4^{\prime}\right) 7.67-7.51(\mathrm{~m}, 3 \mathrm{H}), \mathrm{H} 3^{\prime} 7.07(\mathrm{~d}, J=8.8 \mathrm{~Hz}, 1 \mathrm{H})$, H8 6.23 (d, $J=9.6 \mathrm{~Hz}, 1 \mathrm{H}) .{ }^{13} \mathrm{C}$ NMR: $\left(100.613 \mathrm{MHz}, \mathrm{CDCl}_{3}\right)$ 8/ppm $159.97 \mathrm{C2}^{\prime}, 159.26 \mathrm{C}^{\prime} 0^{\prime}, 154.27$ C9' 151.25 CI, 145.61 C9, 143.65 C7', 142.84 C10, 139.14 C4, 132.30 C6, 131.16 C6', 129.70 C7, 128.51 C8, 127.73 C5, 127.04 C4' , 124.92 C3, 121.68 C5' , 119.94 C2, 118.24 C3' , 117.50 C8' (Figures S5 and S6-S11).

\subsection{Bacterial Strain and Growth Conditions}

A bacterial strain of Flavobacterium psychrophilum (ETECMA) originally isolated from Salmon Coho (Oncorhynchus kisutch) in 2008 in Chiloe, Chile, was used for antibacterial test. Previous experiments performed in the laboratory analyzed the $16 \mathrm{~S}$ gene of this bacterium and showed an identity of $99.6 \%$ with Flavobacterium psychrophilum 10094. The strain was cultivated in TYES broth $(\mathrm{pH}=7.2)$ at $15^{\circ} \mathrm{C}$ for $48 \mathrm{~h}$ with stirring at $180 \mathrm{rpm}$.

\subsection{Antibacterial Test}

To determine MIC, MBC and $\mathrm{IC}_{50}$ of complex and its precursors, microdilution method was performed [29] with some modifications. F. psychrophilum $10094\left(0.4 \mathrm{OD}_{600} \mathrm{~nm}=1 \times 10^{8} \mathrm{CFU} / \mathrm{mL}\right.$, approximately) was inoculated in TYES broth $\mathrm{pH} 7.2$ to $1 \%$ cell suspension in 96-well plates (Falcon) and treated with complex and its precursors in serial concentrations between $512 \mu \mathrm{g} / \mathrm{mL}$ to $2 \mu \mathrm{g} / \mathrm{mL}$ and incubated for $72 \mathrm{~h}$ at $15^{\circ} \mathrm{C}$ with agitation at $180 \mathrm{rpm}$. The MIC was determined as the lowest compounds concentrations which inhibited bacterial grow by visual comparison with the negative control (TYES broth). To determine the MBC, an aliquot of $10 \mu \mathrm{L}$ from MIC was growth on TYES agar plates, $\mathrm{pH} 7.2$, at $20^{\circ} \mathrm{C}$ for $96 \mathrm{~h}$. The $\mathrm{MBC}$ was determined as the minimum concentration of the compounds at which the bacterial colony count was diminish to $99.9 \%$. For determination of the half-maximal inhibitory concentration $\left(\mathrm{IC}_{50}\right)$ of compounds on F. psychrophilum, the $\mathrm{OD}_{600} \mathrm{~nm}$ of each wells was measured using Nanoquant Infinite M200 Pro (TECAN, Grödig, Austria). For the correct calculation of the OD of each concentration of each compound, wells with TYES medium were used with each concentration without inoculating with F. psychrophilum, this control OD was subtracted obtaining the final OD. Data were analyzed using the GraphPad Prism program 5.0. The concentrations 
were transformed into $\log (10)$ and $\mathrm{OD}_{600} \mathrm{~nm}$ normalized in percentage, for the calculation of $\mathrm{IC}_{50}$ a nonlinear regression was performed.

\subsection{Cytotoxicity Test}

Three different cell lines were used to assess the toxicity that the compounds could have on fish: Chinook salmon embryo CHSE-214 (ATCC CRL 1681), Salmon Head Kidney-1 SHK-1 and intestinal epithelial cell line RT-GUT. $1 \times 10^{5}$ Cells were seeded and incubated at $16^{\circ} \mathrm{C}$ for $24 \mathrm{~h}$. Later, the cells were treated with compounds in concentrations from $512 \mu \mathrm{g} / \mathrm{mL}$ to $2 \mu \mathrm{g} / \mathrm{mL}$ solubilized in dimethyl sulfoxide (DMSO, Merck, Darmstadt, Germany) and incubated at $16{ }^{\circ} \mathrm{C}$ for $24 \mathrm{~h}$. Subsequently, the cells were collected, pelleted and resuspended in IF buffer (1X buffer and $2 \%$ fetal bovine serum) and $1 \mu \mathrm{L}$ propidium iodide (PI, $1 \mathrm{mg} / \mathrm{mL}$ ) was added. The cellular viability (negative to PI) was analyzed by flow cytometer using FACSCanto II Cytometer (BD biosciences, University of Santiago of Chile, Santiago, RM, Chile). For positive control, cells were incubated without compounds; for death control, cells were incubated with $50 \%$ ethanol; medium control cells were treated with medium containing $1 \%$ of DMSO. To calculate the $\mathrm{IC}_{50}$ of compounds in the cell lines, they were analyzed using GraphPad Prism program 5.0 (GraphPad Software, San Diego, CA, USA), the concentrations were transformed into $\log (10)$ and the number of events normalized in percentage, for the calculation of $\mathrm{IC}_{50}$ a nonlinear regression was performed.

\subsection{Statistical Analysis}

Statistical analysis was performed using the GraphPad prism 5 program, using a nonparametric Mann-Whitney $t$-test analysis with a $p<0.05$. The analyses were carried out separately for bacteria and for each cell line used.

\section{Conclusions}

A new Copper (I) coordination complex $\left[\mathrm{Cu}\left(\mathrm{NN}_{1}\right)_{2}\right] \mathrm{ClO}_{4}$, where $\mathrm{NN}_{1}$ is 6-((quinolin-2ylmethylene)amino)-2H-chromen-2-one-a ligand derivate from coumarin was synthesized, characterized and evaluated for their antibacterial activity against the pathogen F. psychrophilum.

The $\mathrm{NN}_{1}$ ligand was obtained by several steps by derivatization of coumarin, a natural product with antibacterial activity. The complex was obtained by coordination the ligand to metal in soft reaction condition, with good yield. Its structure was unequivocally established by several NMR techniques, UV-Vis and Cyclic Voltammetry.

In vitro experiments carried out against F. psychrophilum 10094 showed that $\left[\mathrm{Cu}\left(\mathrm{NN}_{1}\right)_{2}\right] \mathrm{ClO}_{4}$ increased its antibacterial capacity compared to coumarin and precursor copper salt $\left(\left[\mathrm{Cu}\left(\mathrm{ACN}_{4}\right)\right] \mathrm{ClO}_{4}\right)$. Although the action mechanism of the copper (I) complex was not studied, the role of this metal ion in the antibacterial activity is evident. The complexation with $\mathrm{NN}_{1}$ ligand would oxidation state maintain and the antibacterial activity in lower amounts of copper making this type of complexes good candidates for the generation of new treatments against F. psychrophilum.

On the other hand, it was observed that in cell lines derived from rainbow trout mucosa (RT-GUT), the application of $\left[\mathrm{Cu}\left(\mathrm{NN}_{1}\right)_{2}\right] \mathrm{ClO}_{4}$ showed a more resistance to toxicity. However, is necessary to complement this with in vivo experiments to determine the real tolerance to complex (I) copper. In this way, the $\left[\mathrm{Cu}\left(\mathrm{NN}_{1}\right)_{2}\right] \mathrm{ClO}_{4}$ could be administered as therapy against $F$. psychrophilum through the fish mucosa by bath or through food. Furthermore, due to the difference in the cytotoxic effects observed of $\left[\mathrm{Cu}\left(\mathrm{NN}_{1}\right)_{2}\right] \mathrm{ClO}_{4}$ on the bacterial cell and eukaryotic cells (SHK-1, CHSE-214), it would be interesting in future studies to analyze the mechanisms by which $\left[\mathrm{Cu}\left(\mathrm{NN}_{1}\right)_{2}\right] \mathrm{ClO}_{4}$ exerts an effect on the permeability of the prokaryotic and eukaryotic cell membrane. With antibacterial activity assays, it is possible to assume that the administration of copper(I)-based drugs as the coordination complexes, is a safe and adequate antimicrobial strategy. 
Supplementary Materials: The supplementary materials are available online. In addition, the spectrum of voltammetry needs to do the characterization of compounds.

Author Contributions: Conceptualization, J.G and B.M.; validation, M.A., M.P. and S.S.; formal analysis, J.G., B.M., M.P., M.A., P.A.; investigation, M.P., M.A.; writing—original draft preparation, M.A., M.P., P.A; B.M., J.G., M.T.; writing-review and editing, M.A., M.P., J.G., B.M., S.S and M.T.; project administration, B.M., J.G.; funding acquisition, B.M., J.G. All authors have read and agreed to the published version of the manuscript.

Funding: This research was funded by Fondo Nacional de Ciencia y Tecnología (FONDECYT) grants 1180265 and 1191902 and the APC was funded by FONDECYT regular 1180265.

Acknowledgments: This work was supported by FONDECYT 1180265 and 1191902, Internal Doctoral Grant USACH and FONDEQUIP EQM150106.

Conflicts of Interest: The authors declare no conflict of interests.

\section{References}

1. Nematollahi, A.; Decostere, A.; Pasmans, F.; Haesebrouck, F. Flavobacterium psychrophilum infections in salmonid fish. J. Fish. Dis. 2003, 26, 563-574. [CrossRef] [PubMed]

2. Barnes, M.E.; Brown, M.L. A review of Flavobacterium psychrophilum biology, clinical signs, and bacterial cold water disease prevention and treatment. Open Fish Sci. J. 2011, 4, 40-48. [CrossRef]

3. Sernapesca. Informe Sanitario de Salmonicultura en Centros Marinos Primer Semestre; Gobierno de Chile: Santiago, RM, Chile, 2018.

4. Jarau, M.; MacInnes, J.I.; Lumsden, J.S. Erythromycin and florfenicol treatment of rainbow trout Oncorhynchus mykiss (Walbaum) experimentally infected with Flavobacterium psychrophilum. J. Fish. Dis. 2019, 42, 325-334. [CrossRef] [PubMed]

5. Lozano, I.; Díaz Pérez, N.; Muñoz Mimiza, S.; Riquelme, C. Antibiotics in chilean aquaculture: A review. In Antibiotic Use in Animals; IntechOpen Limited: London, UK, 2018. [CrossRef]

6. Cabello, F.C. Heavy use of prophylactic antibiotics in aquaculture: A growing problem for human and animal health and for the environment. Environ. Microbiol. 2006, 8, 1137-1144. [CrossRef]

7. Faúndez, G.; Troncoso, M.; Navarrete, P.; Figueroa, G. Antimicrobial activity of copper surfaces against suspensions of Salmonella enterica and Campylobacter jejuni. BMC Microbiol. 2004, 4, 19-25. [CrossRef]

8. Ibrahim, S.A.; Yang, H.; Seo, C.W. Antimicrobial activity of lactic acid and copper on growth of Salmonella and Escherichia coli O157: H7 in laboratory medium and carrot juice. Food Chem. 2008, 109, 137-143. [CrossRef]

9. Gyawali, R.; Ibrahim, S.A.; Abu Hasfa, S.H.; Smqadri, S.Q.; Haik, Y. Antimicrobial activity of copper alone and in combination with lactic acid against Escherichia coli O157: H7 in laboratory medium and on the surface of lettuce and tomatoes. J. Pathog. 2011, 650968-650976. [CrossRef]

10. Speisky, H.; López-Alarcón, C.; Olea-Azar, C.; Sandoval-Acuña, C.; Aliaga, M.E. Role of superoxide anions in the redox changes affecting the physiologically occurring $\mathrm{Cu}$ (I)-glutathione complex. Bioinorg. Chem. Appl. 2011, 674149-674156. [CrossRef]

11. Gaetke, L.M.; Chow, C.K. Copper toxicity, oxidative stress, and antioxidant nutrients. Toxicology 2003, 189, 147-163. [CrossRef]

12. Olah, G.A.; Malhotra, R.; Narang, S.C. Nitration: Methods and Mechanisms; Wiley-Interscience: Weinheim, Germany, 1989; pp. 13-15. ISBN 978-0-471-18695-3.

13. Wang, L.; Li, P.; Wu, Z.; Yan, J.; Wang, M.; Ding, Y. Reduction of nitroarenes to aromatic amines with nanosized activated metallic iron powder in water. Synthesis 2003, 13, 2001-2004. [CrossRef]

14. Whittaker, A.G.; Mingos, D.M.P. The application of microwave heating to chemical syntheses. J. Microw. Power Electromagn. Energy 1994, 29, 195-219. [CrossRef]

15. Hemmerich, P.; Sigwart, C. $\mathrm{Cu}\left(\mathrm{CH}_{3} \mathrm{CN}\right)^{2+}$, ein Mittel zum Studium homogener Reaktionen des einwertigen Kupfers in wässriger Lösung. Experientia 1963, 19, 488-489. [CrossRef]

16. Roy, S.; Mondal, T.K.; Mitra, P.; Torres, E.L.; Sinha, C. Synthesis, structure, spectroscopic properties, electrochemistry, and DFT correlative studies of N-[(2-pyridyl) methyliden]-6-coumarin complexes of $\mathrm{Cu}$ (I) and Ag (I). Polyhedron 2011, 30, 913-922. [CrossRef]

17. Datta, D.; Chakravorty, A. Bis (2-(phenylazo) pyridine) copper (I) and-copper (II): Ligand. pi. acidity and high formal potential of the copper (II)-copper (I) couple. Inorg. Chem. 1983, 22, 1085-1090. [CrossRef] 
18. Martínez, N.P.; Isaacs, M.; Oliver, A.G.; Ferraudi, G.; Lappin, A.G.; Guerrero, J. Effects of non-covalent interactions on the electronic and electrochemical properties of $\mathrm{Cu}$ (i) biquinoline complexes. Dalton Trans. 2018, 47, 13171-13179. [CrossRef] [PubMed]

19. Ambundo, E.A.; Deydier, M.V.; Grall, A.J.; Aguera-Vega, N.; Dressel, L.T.; Cooper, T.H.; Rorabacher, D.B. Influence of coordination geometry upon copper (II/I) redox potentials. Physical parameters for twelve copper tripodal ligand complexes. Inorg. Chem. 1999, 38, 4233-4242. [CrossRef]

20. Khameneh, B.; Iranshahy, M.; Soheili, V.; Bazzaz, B.S.F. Review on plant antimicrobials: A mechanistic viewpoint. Antimicrob. Resist. Infect. Control. 2019, 8, 118. [CrossRef]

21. Galkin, A.; Fallarero, A.; Vuorela, P.M. Coumarins permeability in Caco-2 cell model. J. Pharm. Pharmacol. 2009, 61, 177-184. [CrossRef]

22. Chohan, Z.H.; Iqbal, M.S.; Aftab, S.K. Design, synthesis, characterization and antibacterial properties of copper (II) complexes with chromone-derived compounds. Appl. Organomet. Chem. 2010, 24, 47-56. [CrossRef]

23. Geweely, N.S. Novel inhibition of some pathogenic fungal and bacterial species by new synthetic phytochemical coumarin derivatives. Ann. Microbiol. 2009, 59, 359-368. [CrossRef]

24. Zhao, X.; Drlica, K. Reactive oxygen species and the bacterial response to lethal stress. Curr. Opin. Microbiol. 2014, 21, 1-6. [CrossRef] [PubMed]

25. Clearwater, S.J.; Farag, A.M.; Meyer, J.S. Bioavailability and toxicity of dietborne copper and zinc to fish. Comp. Biochem. Physiol. Part. C Toxicol. Pharmacol. 2002, 132, 269-313. [CrossRef]

26. Chattopadhyay, S.; Dash, S.K.; Tripathy, S.; Das, B.; Mandal, D.; Pramanik, P.; Roy, S. Toxicity of cobalt oxide nanoparticles to normal cells; an in vitro and in vivo study. Chem. Biol. Interact. 2015, 226, 58-71. [CrossRef] [PubMed]

27. Jing, X.; Park, J.H.; Peters, T.M.; Thorne, P.S. Toxicity of copper oxide nanoparticles in lung epithelial cells exposed at the air-liquid interface compared with in vivo assessment. Toxicol. in Vitr. 2015, 29, 502-511. [CrossRef] [PubMed]

28. Sulaiman, G.M.; Tawfeeq, A.T.; Jaaffer, M.D. Biogenic synthesis of copper oxide nanoparticles using olea europaea leaf extract and evaluation of their toxicity activities: An in vivo and in vitro study. Biotechnol. Prog. 2018, 34, 218-230. [CrossRef] [PubMed]

29. Miyake, Y.; Fujiwara, S.; Usui, T.; Suginaka, H. Simple method for measuring the antibiotic concentration required to kill adherent bacteria. Chemotherapy 1992, 38, 286-290. [CrossRef] [PubMed]

Sample Availability: Samples of the compounds are available from the authors.

(C) 2020 by the authors. Licensee MDPI, Basel, Switzerland. This article is an open access article distributed under the terms and conditions of the Creative Commons Attribution (CC BY) license (http://creativecommons.org/licenses/by/4.0/). 